\title{
Does A Market Systems Approach Revitalize Smallholder Irrigation Schemes? Evidence from Zimbabwe
}

\author{
Blessing Masasi ${ }^{1}$ \& John N. Ng'ombe No3 $^{2,3}$ \\ ${ }^{1}$ Department of Biosystems and Agricultural Engineering, Oklahoma State University, Stillwater, OK 74078, \\ USA \\ ${ }^{2}$ Department of Agricultural Economics, Oklahoma State University, Stillwater, OK 74078, USA \\ ${ }^{3}$ Department of Agricultural Economics and Extension, University of Zambia, Box 32379, Lusaka, Zambia \\ Correspondence: Blessing Masasi, Department of Biosystems and Agricultural Engineering, Oklahoma State \\ University, Stillwater, OK 74078, USA. Tel: 1-405-762-0316. E-mail: blessing.masasi@okstate.edu
}

Received: February 14, 2019 Accepted: March 8, 2019 Online Published: March 20, 2019

doi:10.5539/sar.v8n2p36

URL: https://doi.org/10.5539/sar.v8n2p36

\begin{abstract}
Smallholder irrigation schemes potentially improve the livelihoods of rural communities in developing countries. However, they face challenges such as infrastructural decline, lack of funding, lack of markets, shortage of water, underutilization of land, and inefficient irrigation systems. In Zimbabwe, the government carried out rehabilitation programs to address these problems but the performance of smallholder irrigation schemes remained poor. These chronic challenges triggered experts to adopt a market systems approach (MSA) to revitalize failing irrigation schemes. Using primary and secondary data sources collected in 2015, this study used a "before" and "after" descriptive assessment approach to determine the effectiveness of the MSA at revitalizing smallholder irrigation schemes in Zimbabwe. We used Mutema Irrigation Scheme as a case study. Results suggest that the MSA leads to improved efficiency of irrigation infrastructure, farm gross margins, willingness to pay irrigation fees and farmers' standard of living. While this research does not econometrically establish causation of relations between variables involved, our results provide a foundation for future research on the application of the MSA to revitalize underperforming smallholder irrigation schemes in developing countries.
\end{abstract}

Keywords: market systems approach, smallholder irrigation schemes, revitalization, Zimbabwe

\section{Introduction}

Smallholder irrigation is one of the strategies used to boost household incomes and ensure food security in sub-Saharan Africa (SSA) (Burney and Naylor, 2011). FAO (2000) suggest smallholder irrigation schemes potentially enhance agricultural productivity, create employment, ensure food security, and raise incomes and nutrition. In Zimbabwe, Manzungu (1999) reveals that smallholder irrigation schemes significantly contribute to food security, especially in the rural areas. However, most smallholder irrigation schemes in Zimbabwe face persistent challenges. Nhundu and Mushunje (2010) list low productivity, infrastructural decline, water shortage, unavailability of funds for operation and maintenance, lack of markets for produce, and non-coping irrigation systems as the main constraints. In addition, sustainability of smallholder irrigation schemes is threatened by farmers' failure to pay operation and maintenance fees (Moyo, van Rooyen, Moyo, Chivenge, \& Bjornlund, 2017).

In response to the highlighted challenges, the Government of Zimbabwe (GOZ) made significant strides to revive smallholder irrigation schemes by focusing on infrastructural development. For instance, Mabaya (2012) reports that the Quick Fix Programme, an irrigation rehabilitation programme was launched by GOZ through the Department of Irrigation (DOI) as one of the initiatives that targeted infrastructural rehabilitation of smallholder irrigation schemes in Zimbabwe. According to Denison and Manona (2007), this approach only focuses on engineering aspects of smallholder irrigation schemes where repairing water supply infrastructure is a major highlight. However, there had been discussions and calls by several researchers to move away from a rehabilitation approach to more holistic methods like the market systems approach (MSA) to revive underperforming smallholder irrigation schemes in Zimbabwe (Poulton, Dorward, \& Kydd, 2010).

The MSA is a comprehensive approach characterized by: skills and capacity development of farmers, farmer 
linkage to input- and output-markets, availing financial credit services, and infrastructural interventions. Unlike a rehabilitation approach that focuses only on infrastructural maintenance, MSA opens up opportunities for farmers to be empowered with the knowledge to transform their farming activities from subsistence into businesses. In addition, it opens up opportunities for farmers to be equipped with proper marketing strategies coupled with infrastructural development (Denison \& Manona, 2007). Mabaya (2012) argue that the rehabilitation approach yielded minimal results for reviving dysfunctional and underperforming smallholder irrigation schemes in Zimbabwe. Alternatively, Denison and Manona (2007) suggest that since the MSA is comprehensive, its outcomes are more positive and sustainable than the rehabilitation approach. Their argument corroborates the findings by Ferris et al. (2014) who advocated for building smallholder farmers' technical and business abilities in order for them to succeed.

Previous studies recommend the need to improve market access and capacity building to farmers as a possible avenue to rekindle failing smallholder irrigation schemes in Zimbabwe. Some researchers have already created methodologies for implementing the MSA. Denson (2007) developed MSA guidelines to potentially revitalize smallholder irrigation schemes. These guidelines are similar to the framework recommended for smallholder irrigation schemes in Southern Africa by Mwendera and Chilonga (2013). However, Mwendera and Chilonga (2013) and indeed ourselves contend that little knowledge exists about the effects of these revitalization methods on smallholder irrigation schemes and farmers' livelihoods. Thus, the main objective of this research is to determine the impacts of the MSA at revitalizing smallholder irrigation schemes in Zimbabwe. Specifically, using Mutema Irrigation Scheme as the case study, this research attempts to answer the following questions: What change did the MSA have on farm gross margins? What percentage of farmers received training as part of MSA? What impact did the MSA have on water supply infrastructure? What was the effect of MSA on efficiency of infrastructure in Mutema Irrigation Scheme? What was the effect of MSA on farmers' willingness to pay irrigation fees? What was the change in income generation and employment creation for farmers after adoption of MSA? What were/are farmers' perceptions of the MSA as used in reviving their irrigation scheme? Lastly, what are the strengths and weaknesses of the MSA?

As the GOZ and other developing countries seek strategies to revive and boost production in smallholder irrigation schemes to ensure food security, this research provides a launch pad for evaluating the effects of the MSA on farmers' livelihoods. Additionally, this research adds to a dearth of empirical evidence of the effects of the MSA on farmers' welfare and irrigation schemes. Thus, results from this study could be essential for policy-makers seeking solutions to unanswered questions about the plausibility of market systems-based approach at unlocking rural development. This is not only important to Zimbabwe, but also to other developing countries across the world that continue to seek solutions to improve performance of the failing smallholder irrigation schemes.

\subsection{Market Systems Approach}

Market systems approach involves building the capacity and resilience of local structures, leveraging incentives and resources of the private sector, and stimulating change and innovation to continue to grow beyond the project's lifetime. It also ensures that the very poor people benefit economically from such services (U.S. Agency for International Development [USAID], 2014). Keatts (2014) and Denison and Manona (2007) contend that MSA involves training, creation of market based linkages between farmers and firms, breaking barriers between them and ensuring that there are sustainable economic benefits. International development agencies that focus on fostering agricultural development in developing countries have for several years turned their attention to market systems approaches in their programs. Market systems approaches exist in different forms and are therefore carried out differently by different agencies. Taylor (2013) explains that USAID initially encouraged the use of market systems approaches through a value-chain framework but recently encouraged it through a local systems framework that prioritizes sustainability. Taylor (2013) posits that the U.K. Department for International Development (DFID), Australia's Department of Foreign Affairs and Trade, the Swiss Agency for Development and Cooperation (SDC) endorse the same concepts through Making Markets Work for the Poor (M4P) programs.

The MSA that was embraced by USAID in 2010 to revive Mutema Irrigation Scheme in Zimbabwe is a local systems framework focused on sustainability. This approach's main tenet include investment by local actors, for local actors. In addition, USAID's Zimbabwe Agricultural Income and Employment Development Program (Zim-AIED) used this approach to revive dysfunctional smallholder irrigation schemes aimed at increasing agricultural production, rural incomes, and employment creation. To revive Mutema Irrigation Scheme, USAID facilitated financial access by farmers from financial institutions that offered loans to purchase irrigation equipment. Farmers also used these finances to pay for inputs, training services, and the scheme's administrative, operation and maintenance costs. Loans from financial institutions were to be repaid by farmers from their net 
farm incomes after crop sales at the end of the harvest period. USAID and IMC organized farmer trainings to improve farmers' knowledge and irrigation skills.

As discussed in previous research (Mwendera \& Chilonga, 2013; Moyo et al., 2017), ensuring successful revitalization of non-performing smallholder irrigation schemes requires comprehensive frameworks that address the causes of underperformance of such schemes. Key components of those frameworks should include skills and capacity development of smallholder farmers, linking them to input- and output-markets, availing credit and financial facilities while ensuring that the irrigation infrastructure is maintained and operational. As previously discussed, the MSA potentially revives smallholder irrigation schemes by including other developmental aspects in addition to infrastructural development.

\subsection{Smallholder Irrigation Development and Issues in Zimbabwe}

Smallholder irrigation systems in Zimbabwe started in the 1930s. Most of them are located in communal areas characterized by low rainfall and high temperatures (Manzungu, 1999; Makombe, Makadho, \& Sampath, 1998). Manzungu (1999) and Makombe et al. (1998) contend that smallholder irrigation schemes were one of the strategies used by GOZ to boost agricultural productivity all year round in the 1990s. Makombe et al. (1998) disclose that plot sizes in these irrigation schemes ranged from about 0.1 ha to about 10 ha. Government-managed and community-managed irrigation schemes are the main two types of smallholder irrigation schemes in Zimbabwe. Among government-managed schemes, the Department of Irrigation (DOI) and the Department of Agricultural Technical and Extension Service (AGRITEX) manage schemes whereas the Irrigation Management Committees (IMCs) manage community-based schemes (Makombe et al., 1998).

Previous research has shown that smallholder irrigation in Zimbabwe potentially improves farm household incomes, food security, and reduces rural-urban migration because it creates employment and generates wealth (Ruigu \& Rukuni, 1990). While there is a wide consensus about the importance of smallholder irrigation at contributing to agricultural and economic development of Zimbabwe, Dhlodhlo (1997) contends that building market linkages and farmers' technical skills are avenues to increasing viability and sustainability of smallholder irrigation schemes.

But farmers face constraints that hinder the success of these irrigation schemes. Turral (1995) concedes that most smallholder irrigation schemes are characterized by poor performance while Nyagumbo and Rurinda (2011) echo the same findings. Smallholder irrigation schemes in Zimbabwe are characterized by poor performance despite their importance in agricultural and rural development. As for their viability and sustainability, Dhlodhlo (1997) reports that poor managerial skills by farmers and inadequate inputs are major constraints in Zimbabwe. Moyo et al. (2017) suggest that poor access to farm inputs, effective farm implements, operative markets, agricultural knowledge, and poor infrastructure and soil infertility remain the main barriers to sustainable smallholder irrigation schemes in Zimbabwe. Bjornlund, van Rooyen and Stirzaker (2017) point out poor market access and lack of knowledge as drivers for poor performance of smallholder irrigation schemes in whole of SSA In addition, most smallholder irrigation schemes in SSA, particularly in Zimbabwe, are located in the rural and arid regions. As such, smallholder irrigation schemes are vital at addressing food security and poverty reduction for rural communities (Samakande, Senzanje, \& Manzungu, 2004). Thus, the time is ripe to determine whether the MSA revitalized smallholder irrigations schemes in Zimbabwe.

\section{Data and Methods}

\subsection{Study Area and Data Collection}

Mutema Irrigation Scheme is located in Chipinge district of Zimbabwe within the Save catchment, $150 \mathrm{~km}$ south of the city of Mutare. It has Tanganda River to the south, Save River to the west and a mountain range to the north as boundaries. It is located in agro-ecological region 5 which is characterized by a semi-arid climate, with annual rainfall less than $600 \mathrm{~mm}$ and mean temperatures of about $25^{\circ} \mathrm{C}$ (Chemura, Kutywayo, Chagwesha, \& Chidoko, 2014). The rain season spans from December through March. Location and the aerial view from Google Earth of the scheme are shown in Fig. 1. 


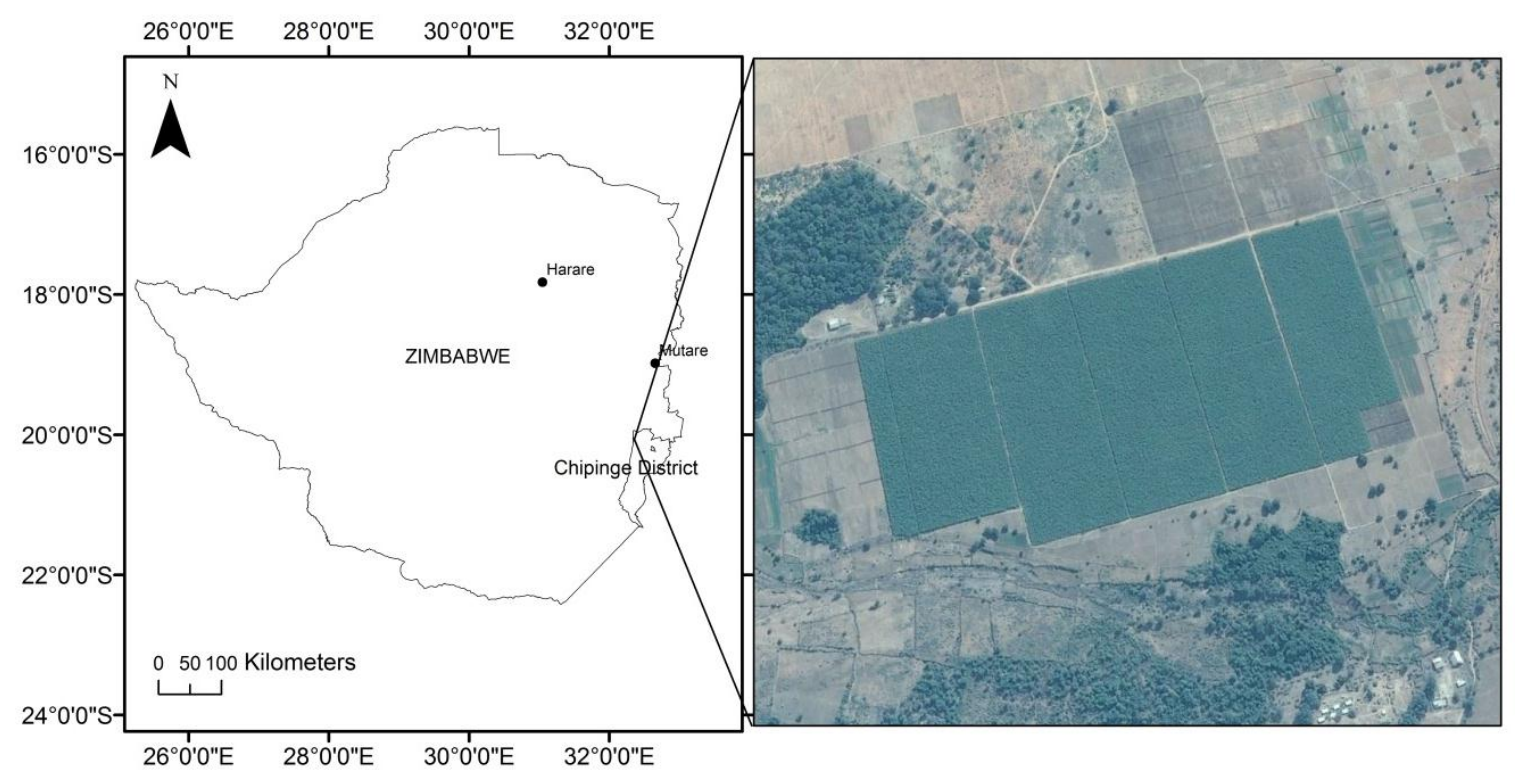

Figure 1. Location of Mutema Irrigation Scheme and its Google Earth satellite image

This study adopts a descriptive empirical approach where both qualitative and quantitative data were collected from primary and secondary sources. Semi-structured interviews were conducted with key informants from Fintrac Inc, which was USAID's implementing agency at the scheme. Key informants included the Program Manager and the Field Manager from Fintrac Inc, agricultural extension workers of AGRITEX, and the chairperson of Mutema Irrigation Scheme's IMC. Interviews with key informants were meant to establish a better understanding of the MSA and how it was implemented to revive the irrigation scheme.

Semi-structured interviews are flexible because they allow the interviewer to deviate from the main subject to ensure a better understanding of views and perceptions of interviewees (Gill, Stewart, \& Chadwick, 2008). In terms of sampling, we employed a simple random sampling using R Software (R Core Team, 2015). A simple random sampling procedure ensured that each farmer had an equal and non-zero probability of being selected in the sample. The Mutema Irrigation Scheme had a total of 238 farmers from which we took a sample of 30 farmers. This sample represented about $13 \%$ of the farmers in the scheme. As suggested by Roscoe (1975), the choice of sample size mostly depends on monetary and time resources available rather than statistics. Roscoe (1975) suggested a minimum sample size of 30 when resources are limited, which was the case for this study because our resources were quite limited. Additionally, Alreck and Settle (1995) recommend a sample size of 10\% of the population while Gay and Diehl (1992) also endorse a sample size that covers at least $10 \%$ of the population for descriptive research like the present study.

Our questionnaires were comprised of both open- and closed-ended questions. We collected data on the farmers' livelihoods that included income levels, assets, standard of living, and employment creation. It is worth mentioning that data collection was conducted in 2015, five years after the MSA had been instituted. Our survey also captured information about land and crop productivity, capacity building and people's perceptions about the MSA. Pre-testing of the questionnaire was done on four farmers. The questionnaire was administered on a face-to-face mode at Mutema Irrigation Scheme, the Agricultural Technical and Extension Service (AGRITEX) offices, farmers' fields and homesteads. Interviews were conducted in Shona - the area's native language. To grasp more insights, secondary data based on records and reports was acquired from AGRITEX, IMC and Fintrac. AGRITEX provided useful insights especially about the scheme's status prior to the MSA.

\subsection{Data Analysis}

Data analysis involved descriptive statistics, content analysis and the generally accepted irrigation performance indicators. Descriptive analysis focused on farmer incomes, land, and crop productivity in Mutema Irrigation Scheme. Irrigation performance assessment indicators were chosen based on research questions. We used the following irrigation performance assessment indicators: farm gross margins, percentage of farmers that received trainings, efficiency of infrastructure, fee collection index, irrigation wage generation, irrigation employment generation, and famer satisfaction. We adopted these performance indicators from Bos, Burton and Molden 
(2005). Gross margins indicated the difference between total revenue and total variable costs that a farmer incurred during the agricultural production process (Beattie, Taylor, \& Watts, 1985). Total revenue is computed as the product of price and quantity of a commodity while total variable costs are total expenses of variable inputs in the production process. The efficiency of infrastructure indicated the status of operation and maintenance of infrastructure in the scheme. It was computed as the ratio of the number of functioning structures to the total number of structures in the irrigation scheme. Fee collection index was used to determine willingness and the ability of farmers to pay for irrigation fees. It was computed as a ratio of irrigation fees collected to irrigation fees due.

In addition, irrigation wage generation was used to compare farmers' capacity to generate agricultural income and employment creation prior to and after adopting the MSA. It was expressed as a ratio of annual average agricultural income to annual national average agricultural income. The irrigation employment generation indicator was used to capture both the scheme's and surrounding region's capacity to create employment. This index was computed as the ratio of annual person days per hectare in the scheme to the annual number of working days. Farmers' satisfaction index was used to measure the degree of satisfaction perceived by the farmers about the MSA relative to previous efforts to revive the scheme. This was determined from farmers' perceptions about the revitalization approach using a 3-Likert scale ranked as "worse than," "same as," and "better than."

\section{Results and Discussion}

\subsection{Farm Gross Margins}

Before the MSA, traditional cash crops included tomatoes and maize that were grown in winter and summer, respectively. Average yields of tomatoes and maize were $15 \mathrm{Mg} / \mathrm{ha}$ and $0.8 \mathrm{Mg} / \mathrm{ha}$, respectively. According to AGRITEX key informants, the potential yield for tomatoes is $30 \mathrm{Mg} / \mathrm{ha}$ while it is $6 \mathrm{Mg} / \mathrm{ha}$ for maize in Zimbabwe. These values indicate that Mutema Irrigation Scheme was recording low crop productivity levels. Because of low productivity, farmers on average incurred revenue losses of about US $\$ 517$ per ha per year. Following the revitalization process, farmers shifted to banana production. According to key informants from AGRITEX, bananas are a higher valued crop than tomatoes and maize in Zimbabwe. In terms of yields, the average banana yield was about $16.25 \mathrm{Mg} / \mathrm{ha}$ over the first three years after MSA was adopted, resulting in gross incomes of close to US $\$ 4062$ per ha per year. The total average variable costs for growing bananas per year was US\$1481 per ha in the same period. This resulted in farmers realizing average gross margins of about US\$2581 per ha per year after revitalization of the irrigation scheme. These results clearly indicate a significant increase in farmer incomes due to adoption of a high valued crop through the MSA.

\subsection{Training of Farmers and Government Extension Staff}

Based on interviews with AGRITEX key informants, prior to the MSA revitalization, government extension workers lacked the capacity to train farmers in various aspects of agriculture particularly in agribusiness management. This made it difficult for farmers to receive the necessary training that would enhance their knowledge and skills. It was further revealed that before the MSA, some farmers claimed to be more knowledgeable than the available extension workers. Thus, as part of the revitalization, extension workers were also engaged to receive training in agribusiness management. The trainers were specialists from Fintrac Inc. These trainings largely improved confidence of extension workers compared to the period before implementation of the MSA. In the survey, respondents were asked to indicate the number of trainings that they had received before and after the MSA. It was established that most of the farmers that were trained prior to revitalization were generally older ones who had received some training during the early 1990s. During that period, trainings only focused on the scheme's agronomic aspects. However, survey results showed that $97 \%$ of farmers had received training during the revitalization process. Trainings concentrated on enhancing agribusiness and crop management skills of farmers. The main topics covered were Farming as a Business, Record Keeping, Marketing, Budgeting, Contract Farming and Crop Management.

\subsection{Irrigation Water Supply Infrastructure}

Based on AGRITEX records, prior to the MSA, Mutema Irrigation Scheme's infrastructure was not in a good state due to cyclone Eline that took place in 2000. Three of the scheme's boreholes were destroyed. Table 1 presents a summary of the status of the scheme's boreholes and pumps before the MSA. 
Table 1. Status of Boreholes and Pumps Before MSA

\begin{tabular}{lllll}
\hline Borehole number & Yield $(1 / \mathrm{s})$ & Motor size $(\mathrm{Hp})$ & Depth $(\mathrm{m})$ & Status \\
\hline 1 & 35 & 54 & 26 & Washed away by cyclone \\
2 & 21 & 30 & 30 & Washed away by clone \\
3 & 85 & 200 & 26 & Worn shaft \\
4 & 54 & 75 & 26 & Washed away by cyclone \\
\hline
\end{tabular}

Source: Chidenga (2003).

There was only one functioning borehole indicated as borehole number 3 in Table 1 before the revitalization. According to DOI's reports, this situation resulted in Mutema Irrigation Scheme operating at $10 \%$ capacity in terms of irrigation water supply. The DOI's reports also point out a lack of operational funds as a source of the existing problem. Basically, operation and maintenance in Mutema Irrigation Scheme was funded from irrigation fees paid by the farmers. However, farmers rarely paid irrigation fees before the MSA was implemented. Following the MSA, the situation improved because farmers were able to pay irrigation fees from crop incomes. Table 2 presents a summary of the status of water supply pumps at Mutema Irrigation Scheme before and after revitalization.

Table 2. Summary of Functional and Non-Functional Water Supply Pumps Before and After MSA

\begin{tabular}{lll}
\hline Status of pump & Before & After \\
\hline Functional & 1 & 3 \\
Non-functional & 3 & 1 \\
Total & 4 & 4 \\
\hline
\end{tabular}

After revitalization, the scheme had three functional boreholes in 2015 indicated in Table 2. This enhanced availability of irrigation water to the scheme. As suggested by Mutambara and Munodawafa (2015), non-coping irrigation infrastructure, poor servicing and maintenance of pumps are major factors contributing to low productivity of smallholder irrigation schemes in Zimbabwe. This was consistent with the case of Mutema Irrigation Scheme where only one of the four boreholes was operational before the MSA. As pointed out before, through the MSA, the USAID facilitated acquisition of loans from financial institutions which required farmers to pay from their farm incomes. These loans led to installation of two more boreholes in the scheme. The new boreholes improved water supply for irrigation. From what we observed, availability of irrigation water improved and the area under production rose from 15 ha to 90 ha. Most importantly, according to key informants, leakages that occurred in the main line and lateral pipes before revitalization were repaired. This resulted in larger quantities of water reaching crop fields, leading to increased productivity relative to prior years before the revitalization. These findings are in agreement with Malano and van Hofwegen (1999) who argued that productivity in irrigated agriculture is affected to a large extent by efficient irrigation and drainage services.

\subsection{Efficiency of Infrastructure}

The efficiency of infrastructure prior to and after implementing the MSA was determined based on recorded information and observations of functioning and non-functioning irrigation pumping stations at Mutema Irrigation Scheme. Results indicate that efficiency of infrastructure increased from 25\% before MSA to $75 \%$ after revitalization, implying significant improvement of water supply after revitalization.

Before the MSA, the irrigation scheme was irrigated using inefficient surface and portable overhead irrigation systems (Masasi, 2015). This scenario compounded water supply problems. However, using the acquired loans from financial institutions, farmers replaced the inefficient irrigation systems with a more efficient micro-jet irrigation system. According to key informants, the micro-jet irrigation system led to water savings and enhanced adequacy in the irrigation scheme. Based on interview responses, farmers highlighted that the micro-jet irrigation system also saved labor spent on irrigation relative to the portable overhead sprinkler system where more labor was required to move lateral pipes.

\subsection{Farmers' Willingness to Pay Irrigation Fees}

Before the MSA, Mutema Irrigation Scheme owed significant amount of money to the Zimbabwe Electricity Supply Authority (ZESA) and Zimbabwe National Water Authority (ZINWA) for electricity and water supply, respectively. According to Mutema Irrigation Scheme's records, the scheme owed the two companies in excess of US $\$ 35,000$. The money accrued as farmers failed to pay irrigation water and electricity bills over the years. 
Farmers argued that their failure to pay these bills was a result of low incomes they got from agricultural production in the scheme. However, after the implementation of the MSA, farmers' incomes improved considerably. This resulted in improved payment of irrigation fees in the irrigation scheme. As of 2015 when data for this research were collected, the accounting records obtained from DOI and AGRITEX showed that the irrigation scheme had zero arrears for water supply and electricity. Previous bills were paid for by part of funds from loans and incomes generated from banana sales. This was an indication that farmers' ability to pay for irrigation fees was enhanced as a result of increased gross margins from banana production.

The survey revealed that before revitalization, most farmers were generally unwilling to pay irrigation fees because they did not see the need to since the scheme was not functional and irrigation water could not reach their fields most of the time. Following the MSA, farmers were more willing to pay their irrigation fees. The MSA led to improved irrigation water supply, which in turn increased agricultural productivity and incomes for farmers. As the scheme continued to thrive, farmers were more willing to settle outstanding bills and no new arears accrued post MSA.

The information acquired from the interview with the chairperson of IMC and the record of fees after the MSA that were obtained from the DOI allowed us to establish the fee collection index for Mutema Irrigation Scheme. Results suggest that around $15 \%-20 \%$ of the farmers were both able and willing to pay irrigation service fees before the MSA but this value rose to $100 \%$ after.

\subsection{Incomes and Employment Generation}

We determined employment generation using the number of days that farmers worked on their respective plots in the irrigation scheme before and after revitalization. Farmers were also asked to provide data about working hours spent on the fields and the number of people on average that would be working per day. As shown in Table 3 , on average farmers worked for 2 and 5 days before and after revitalization, respectively.

Table 3. Irrigation Employment Generation Indicator

\begin{tabular}{lll}
\hline & Before & After \\
\hline Average working hours per day & 2 & 5 \\
Annual man-days per hectare & 416 & 1040 \\
Irrigation employment generation indicator (per ha) & 2 & 5 \\
\hline
\end{tabular}

Furthermore, the number of persons employed in the irrigation scheme increased from 2 people per ha before, to 5 people per ha after the MSA. Our results indicate that the time spent on the fields increased from about 2 to 5 hours on average before and after the MSA, respectively. We attribute these findings among other things to the refurbished water system that resulted in improved water availability in the scheme since farmers then had an all-year round crop production. Almost all the farmers who participated in the survey revealed that prior to the MSA, there was barely nothing in the fields as crops wilted due to water shortages and as such they did not see reason to go to their fields more frequently.

Following the MSA, and as previously discussed, most farmers in Mutema Irrigation Scheme shifted from traditional crops to banana production, which generated more revenue throughout the year. The USAID linked farmers to Matanuska Ltd, one of the major banana buyers in the country. Matanuska Ltd established a selling plant at the irrigation scheme and hired people from local communities. New employment opportunities included banana grading, cleaning, packaging, and accounting among others. According to key informants from AGRITEX, the unemployment rate in Mutema communal lands stood at $80 \%$ within the communities before the MSA, but the unemployment rate in the communities was reduced to around $40 \%$ by early 2015 . Farmers also indicated that the crime rate was reduced, as most people were included in the micro-economy.

\subsection{Farmers' Perceptions of the Market Systems Approach and Changes in Standard of Living}

In the survey, we further explored farmers' perceptions about the MSA as one way for revitalization. Results indicate that $100 \%$ of farmers described the approach as a better and more useful tool for revitalization than other previous efforts by government and other stakeholders. Past attempts focused on rehabilitating infrastructure after which the implementers just left with no form of training or having an established market. Farmers also identified the availability of the input- and output-markets, availability of finance access and installation of efficient irrigation system as the MSA's positive outcomes.

In terms of farmers' quality of life after the MSA, we ranked their opinions on Likert scale with options: "better than," "same as," and "worse than." Our results show that about $97 \%$ of farmers in the sample indicated the 
option "better than" while about $3 \%$ indicated that their lifestyle was "same as" before the MSA.

\subsection{Strengths and Weakness of Market Systems Approach}

Just as the coin has two sides, our results show that farmers believe that the MSA is not an all-problem solving approach despite having both revitalized the failing irrigation scheme and improved their standard of living. As applied in Mutema Irrigation Scheme and based on respondents in the sample, the main limitation of the approach in this case study is that one buyer was pre-identified. As previously discussed, Matanuska Ltd was the sole buyer of bananas in the scheme. This created a monopoly in the output-market resulting in only the firm determining the price of bananas. The absence of other competing buyers would give the buyer an added edge over the farmers. Additionally, there was asymmetry of price information, which created a possibility of farmers not realizing the true value of their product on the market. According to survey results, the main reason for this was that farmers were not involved in pricing their produce. This at times triggered panic in farmers and mistrust in the buyer as they felt they were being duped.

\section{Conclusions}

This study sought to establish if the market systems approach (MSA) can revitalize smallholder irrigation schemes, using Mutema Irrigation Scheme in Zimbabwe as a case study. Based on our findings, water shortage which is common to most smallholder irrigation schemes in Zimbabwe and SSA may not be addressed or solved only by rehabilitation of infrastructure alone. There is a need for both the farmers and technical experts managing the schemes to realize that in some cases their irrigation system is not adequate anymore. This was shown in the case of Mutema Irrigation Scheme where an inefficient surface irrigation system was replaced with a more efficient micro-jet irrigation system that conserves water and improves irrigation adequacy. The MSA made financial access by farmers possible resulting in procurement of necessary farming inputs for optimum crop production. The enhanced market access as a result of MSA improved farmers' income unlike before revitalization where markets were scarce. However, we found that the unilateral output-market system, where farmers sell their agricultural produce to a sole buyer limits the farmers' bargaining power for a good price, yet at the same time, it benefits the buyer. Smallholder farmers should also be involved in pricing their produce. This would enhance trust between buyers and farmers. Failure to involve farmers has a negative bearing on the sustainability of the schemes. Additionally, farmers have to be trained on how markets operate so that they will understand the market forces causing the rise and fall of prices for their produce.

This study has shown that linking farmers to well-established markets is one of the strongest factors that lead to the successful revitalization of smallholder irrigation schemes. For the case of Mutema Irrigation Scheme, during the period preceding revitalization, farmers had difficulties in selling their produce due to unavailability of markets. The guaranteed market following revitalization meant that the farmers would access credit facilities to procure inputs and resources for crop production. Alternatively, the creation of multilateral markets would perhaps enhance prices for the farmers' produce ultimately improving farmers' agricultural incomes.

As in every research, there are caveats worth mentioning. Our study was merely descriptive and thus hypotheses could not be tested. There could be other factors that we did not account for which might have contributed to changes in performance of Mutema Irrigation Scheme after the market systems approach. Ideally, additional surveys using larger samples than used in this study, employing micro-econometric methods to establish the real impact of MSA at revitalizing smallholder schemes are recommended for future research. However, our results provide a platform for future research on revitalization of smallholder irrigation schemes in developing countries.

\section{Acknowledgments}

Authors acknowledge the contributions from ZIM-AIED managers, Mr. Benson, Mr. Mutocho, Mr. Zimunya, and officers of the Department of Agricultural Extension (AGRITEX) at Mutema Irrigation Scheme for their assistance during data collection.

\section{References}

Alreck, P. L., \& Settle, R. B. (1995). The Survey Research Handbook: Guidelines and Strategies for Conducting a Survey. Chicago IL: McGraw-Hill.

Beattie, B. R., Taylor, C. R., \& Watts, M. J. (1985). The economics of production. New York, NY: Wiley.

Bjornlund, H., van Rooyen, A., \& Stirzaker, R. (2017). Profitability and productivity barriers and opportunities in small-scale irrigation schemes. International Journal of Water Resources Development, 33(5), 690-704. https://doi.org/10.1080/07900627.2016.1263552 
Bos, M. G., Burton, M. A., \& Molden, D. J. (2005). Irrigation and drainage performance assessment: practical guidelines. Wallingford, U.K: CABI Publishing.

Burney, J. A., \& Naylor, R. L. (2012). Smallholder irrigation as a poverty alleviation tool in sub-Saharan Africa. World Development, 40(1), 110-123. https://doi.org/10.1016/j.worlddev.2011.05.007

Chemura, A., Kutywayo, D., Chagwesha, T. M., \& Chidoko, P. (2014). An assessment of irrigation water quality and selected soil parameters at Mutema Irrigation Scheme, Zimbabwe. Journal of Water Resource and Protection, 6(02), 132. https://doi.org/10.4236/jwarp.2014.62018

Chidenga, E. E. (2003). Leveraging water delivery. Irrigation technology choices and operations and maintenance in smallholder systems in Zimbabwe (Doctoral dissertation, Wageningen University, Wageningen, Netherlands). Retrieved from https://library.wur.nl/WebQuery/wurpubs/fulltext/121451

Denison, J., \& Manona, S. (2007). Principles, approaches and guidelines for the participatory revitalisation of smallholder irrigation schemes. Pretoria, SA: Water Research Commission.

Dhlodhlo, R. (1997). Assessment of the Socio-economic Impact of Smallholder Irrigation Development on Smallholder Farmers in Zimbabwe. Rome, Italy: Food and Agriculture Organisation.

FAO (2000). Socio-economic impact of smallholder irrigation development in Zimbabwe. Retrieved from http://fao.org/3/X5594E/X5594e00.htm

Ferris, S., Robbins, P., Best, R., Seville, D., Buxton, A., Shriver, J., \& Wei, E. (2014). Linking smallholder farmers to markets and the implications for extension and advisory services. Retrieved from https://www.agrilinks.org/sites/default/files/resource/files/MEAS\%20Discussion\%20Paper\%204\%20-\%20L inking\%20Farmers\%20To\%20Markets\%20-\%20May\%202014.pdf

Gay, L. R., \& Diehl, P. L. (1992). Research methods for business and management. New York, NY: McMillan.

Gill, P., Stewart, K., Treasure, E., \& Chadwick, B. (2008). Methods of data collection in qualitative research: interviews and focus groups. British dental journal, 204(6), 291. https://doi.org/10.1038/bdj.2008.192

Keatts, A. (2014). A Market Systems Approach in the Agricultural Sector: Sustainable Service Delivery for Smallholder Farmers. Retrieved from

https://www.agrilinks.org/library/market-systems-approach-agriculture-sector-sustainable-service-delivery-s mallholder-farmers

Mabaya, G. (2012). Refinement of principles and procedures for effective modernization of Al model irrigation schemes in Zimbabwe: case study of Igudu Al model irrigation scheme. (MSc. Thesis, UNESCO-IHE, Delft, Netherlands). Retrieved from https://un-ihe.on.worldcat.org/oclc/795888126

Makombe, G., Makadho, J. M., \& Sampath, R. K. (1998). An analysis of the water management performance of small holder irrigation schemes in Zimbabwe. Irrigation and Drainage Systems, 12(3), 253-263. https://doi.org/10.1023/a:1006113402381

Malano, H. M., \& van Hofwegen, P. (1999). Management of irrigation and drainage systems. Boca Raton, FL: CRC Press.

Manzungu, E. (1999). Strategies for smallholder irrigation management in Zimbabwe. (Doctoral dissertation, Wageningen University, Wageningen, Netherlands). Retrieved from https://library.wur.nl/WebQuery/wurpubs/62306

Masasi, B. (2015). Impact assessment of the market systems approach for revitalisation of smallholder irrigation schemes in Zimbabwe: Case study of Mutema Irrigation Scheme (MSc. Thesis, UNESCO-IHE, Delft, Netherlands). Retrieved from https://un-ihe.on.worldcat.org/oclc/909258665

Moyo, M., Van Rooyen, A., Moyo, M., Chivenge, P., \& Bjornlund, H. (2017). Irrigation development in Zimbabwe: Understanding productivity barriers and opportunities at Mkoba and Silalatshani irrigation schemes. International Journal of Water Resources Development, 33(5), 740-754. https://doi.org/10.1080/07900627.2016.1175339

Mutambara, S., \& Munodawafa, A. (2014). Production challenges and sustainability of smallholder irrigation schemes in Zimbabwe. Journal of biology, agriculture and healthcare, 4(15), 87-96. Retrieved from http://citeseerx.ist.psu.edu/viewdoc/download?doi=10.1.1.1001.5825\&rep=rep1\&type=pdf

Mwendera, E., \& Chilonda, P. (2013). Conceptual framework for revitalisation of small - scale irrigation schemes in southern africa. Irrigation and drainage, 62(2), 208-220. https://doi.org/10.1002/ird.1723 
Nhundu, K., \& Mushunje, A. (2010). Analysis of irrigation development post fast track land reform programme. A case study of Goromonzi District, Mashonaland East Province, Zimbabwe. Joint 3rd African Association of Agricultural Economists (AAAE) and 48th Agricultural Economists Association of South Africa (AEASA) Conference. Retrieved from https://ideas.repec.org/s/ags/aaae10.html

Nyagumbo, I., \& Rurinda, J. (2012). An appraisal of policies and institutional frameworks impacting on smallholder agricultural water management in Zimbabwe. Physics and Chemistry of the Earth, Parts $A / B / C, 47,21-32$. https://doi.org/10.1016/j.pce.2011.07.001

Poulton, C., Dorward, A., \& Kydd, J. (2010). The future of small farms: New directions for services, institutions, and intermediation. World Development, 38(10), 1413-1428. https://doi.org/10.1016/j.worlddev.2009.06.009

R Core Team. (2015). R: A language and environment for statistical computing. Retrieved from https://www.R-project.org/

Roscoe, J. T. (1975). Fundamental Research Statistics for the Behavioral Sciences. New York, NY: Rinehart and Winston, Inc.

Ruigu, G. M., \& Rukuni, M. (1990). Irrigation policy in Kenya and Zimbabwe: Proceedings of the second intermediate seminar on irrigation farming in Kenya and Zimbabwe. In 2. Intermediate seminar on irrrigation farming in Kenya and Zimbabwe. Retrieved from http://hdl.handle.net/11295/39744

Samakande, I., Senzanje, A., \& Manzungu, E. (2004). Sustainable water management in smallholder irrigation schemes: Understanding the impact of field water management on maize productivity on two irrigation schemes in Zimbabwe. Physics and Chemistry of the Earth, Parts A/B/C, 29(15-18), 1075-1081. https://doi.org/10.1016/j.pce.2004.08.009

Taylor, B. (2013). Evidence-Based Policy and Systemic Change: Conflicting Trends?. SSRN Electronic Journal. https://doi.org/10.2139/ssrn.2304208

Turral, H. (1995). Recent trends in irrigation management: Changing directions for the public sector. Natural Resource Perspectives, 5. Retrieved from https://www.odi.org/sites/odi.org.uk/files/odi-assets/publications-opinion-files/2981.pdf

U.S. Agency for International Development. (2014). Local Systems: A Framework for Supporting Sustained Development. Retrieved from https://www.usaid.gov/policy/local-systems-framework

\section{Copyrights}

Copyright for this article is retained by the author(s), with first publication rights granted to the journal.

This is an open-access article distributed under the terms and conditions of the Creative Commons Attribution license (http://creativecommons.org/licenses/by/3.0/). 